Int. J. Dev. Biol. 61: 225-234 (2017)

doi: $10.1387 / \mathrm{ijdb} .160393 \mathrm{ra}$

\title{
The retinal pigmented epithelium - from basic developmental biology research to translational approaches
}

\author{
BENJAMIN AMRAM", YAMIT COHEN-TAYAR\#, AHUVIT DAVID* and RUTH ASHERY-PADAN* \\ Department of Human Molecular Genetics and Biochemistry, Sackler Faculty of Medicine, Tel Aviv University, \\ Tel Aviv, Israel
}

\begin{abstract}
The development of the eye has been a topic of extensive investigation, from the early studies on tissue induction to more recent breakthroughs in resolving the mechanism regulating progenitor patterning and their gradual and coordinated differentiation into diverse tissue types that function together throughout life. Among the ocular tissue types, the retinal pigmented epithelium (RPE) is at the forefront of developmental biology and stem cell research. The growing interest in this lineage stems from its importance for photoreceptor function as well as from its requirement during embryogenesis for the development of the photoreceptors and the choroid. Indeed mutations in RPE genes and epigenetic changes that occur during aging are the cause of monogenic as well as multifactorial retinal diseases. Importantly, the RPE is readily generated from stem cells, and these stem cell-derived RPE cells are currently being tested in clinical trials for transplantation in cases of retinal dystrophies; they also constitute an important model to study developmental processes in vitro. This review summarizes recent advances in our understanding of RPE development and its requirement for the development of photoreceptors and choroidal vasculature. We discuss the contribution of basic findings to therapeutic applications and the future challenges in uncovering developmental processes and mimicking them ex vivo to further advance research and therapy of retinal disorders.
\end{abstract}

KEY WORDS: RPE, photoreceptor, choroidal vasculature, retina

\section{Introduction}

Photoreceptors (PRs) and pigment cells form a functional unit which is found in various types of eyes in the different animal phyla (Arendt, 2003, Charlton-Perkins and Cook, 2010, Gehring, 2014). In vertebrates, the ocular pigmented cells form a single layer of polarized epithelium termed retinal pigmented epithelium (RPE), which is located between the PRs and choroidal vasculature. The RPE has multiple and complex functions required for PR development, homeostasis and physiology (Strauss, 2005).

RPE functions are executed by distinct cellular compartments. The apical side of the RPE extends microvilli, which are long and thin actin processes that engulf the outer segments of the PRs and are required for their daily renewal by phagocytosis (Bonilha, 2014; reviewed in Kevany and Palczewski, 2010). The basal side the RPE is attached to the anterior layer of Bruch's membrane, a connective tissue that separates the RPE from the choriocapilaris and is an important component of the blood-retina barrier (BRB; Bhutto and Lutty, 2012, Rahner et al., 2004). The interaction of the RPE with Bruch's membrane consists of basal infoldings, short invaginations which increase the surface area of the RPE (Bonilha, 2014). The polarized distribution of ion channels and transporters in the RPE further enable it to control the composition of the subretinal space and to support survival and function of the PRs and other retinal cell types (Lehmann et al., 2014).

Considering the importance of the RPE to PR survival and activ-

\footnotetext{
Abbreviations used in this paper: AMD, age-related macular degeneration; BRB, blood-retina barrier; EMT, epithelial to mesenchyme transition; FGF, fibroblast growth factor; HD, homeodomain; IHH, Indian hedgehog; iPSC, induced pluripotent stem cell; miRNA, microRNAs; NR, neuroretina; OC, optic cup; OV, optic vesicle; PEDF, pigmented epithelium-derived factor; PR, photoreceptor; pSMAD, phosophorylated smad; RA, retinoic acid; RPE, retinal pigmented epithelium; SE, surface ectoderm; SHH, Sonic hedgehog; TF, transcription factor.
}

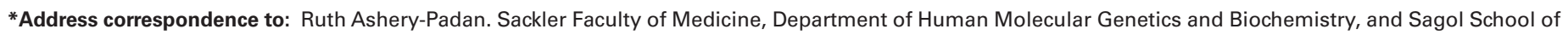
Neuroscience, Tel Aviv University, Tel Aviv 69978, Israel.Tel: +97236409331. Fax: +97236405834. E-mail: ruthash@post.tau.ac.il

\#Note: The first three authors contributed equally to the manuscript.

Accepted: 4 January, 2017.

ISSN: Online 1696-3547, Print 0214-6282 
ity, it is not surprising that RPE dysfunctions are associated with various retinal dystrophies, including the common cause of agingrelated blindness in humans - age-related macular degeneration (AMD, Jackson et al., 2002; Wright et al., 2010). Stem-cell-based therapies for RPE dysfunctions are currently being evaluated in clinical trials (Carr et al., 2013, Song and Bharti, 2015). Thus, resolving the gene regulatory networks functioning in the course of RPE development and regulating its multiple activities is of interest for the field of regenerative medicine. In this review, we summarize the findings on RPE differentiation and maintenance, and the progress - as well as the challenges - in stem cell technologies aimed at replacing damaged RPE with healthy tissue for the purpose of preserving and regenerating retinal function.

\section{Gene regulatory networks involved in establishing the progenitor domains of the optic cup}

In humans and other vertebrates, the sensory neural retina and pigmented lineages of the eye originate during embryonic development from an outgrowth of the ventral forebrain termed optic vesicle (OV). The oval OV rapidly undergoes morphogenesis to become the hemispheric optic cup (OC, Kwan et al., 2012; Picker et al., 2009). The dorsal outer layer of each OC will form the RPE, the ventral outer layer will give rise to the optic stalk, and the inner layer of the $\mathrm{OC}$ contains the pseudostratified retinal progenitor cells that proliferate and gradually differentiate into retinal lineages (Shaham et al., 2012). The borders between inner and outer layers of the OC will give rise to the non-neuronal, pigmented epithelia of the ciliary body and iris (Davis-Silberman and Ashery-Padan, 2008).

The OV originates from a group of cells at the anterior neural plate that express a combination of transcription factors (TFs) important for forebrain and eye development (reviewed in Fuhrmann et al., 2014; Sinn and Wittbrodt, 2013). These TFs include the homeodomain (HD) proteins Six3, Otx2 and Rx, the paired and HD protein Pax6, and the LIM-HD domain protein Lhx2. In the $\mathrm{OV}$, these TFs play multiple roles. $\mathrm{Rx}$ and $\mathrm{Lhx} 2$ are required for OV morphogenesis and later, together with Pax6, Otx2 and Six3, function to maintain ocular fates and proliferation of the early neuroepithelial progenitors (Bovolenta et al., 1997; Farhy et al., 2013; Oron-Karni et al., 2008; Philips et al., 2005; Porter et al., 1997; Roy et al., 2013; Gueta et al., 2016). At later stages, these factors are further involved in the differentiation of specific retinal cell types (Beby and Lamonerie, 2013, de Melo et al., 2016, Emerson et al., 2013, Gordon et al., 2013, Koike et al., 2007, Muranishi et al., 2011, Samuel et al., 2016).

In the RPE, Mitf is considered to be the earliest indication of a pigmented epithelium fate. Mitf is a basic helix-loop-helix leucine zipper protein and a key regulator of pigment cell development from both the neural crest and neural epithelium as it transactivates crucial genes for pigment biogenesis (e.g. Dct, Tyrp1 and Tyr) (Tachibana, 2000, Tachibana et al., 1994). Mutations in Mitf result in the generation of neuroretina (NR) instead of RPE, whereas ectopic expression of Mitf in the NR prevents neurogenesis and triggers expression of genes involved in pigment biogenesis (Horsford et al., 2005, Nguyen and Arnheiter, 2000). Mitf is detected in the OV of mouse embryos prior to division of the pigmented and neural progenitor domains and by the OC stage, its expression is restricted to the pigmented lineages (Baumer et al., 2003,
Nguyen and Arnheiter, 2000). Mitf regulation has therefore been extensively investigated to resolve the mechanisms involved in early patterning of the OC. Mitf contains multiple promoters (Bharti et al., 2008). The variants expressed in the RPE are Mitf $A, J, H$ and $\mathrm{D}$, in contrast to Mitf $\mathrm{M}$, which is predominant in melanocytes (Bharti et al., 2008). Studies of mutants in specific Mitf variants have revealed a compensatory mechanism among these variants, as downregulation of one leads to upregulation of others, as well as of another Mitf family member, TFEC (Bharti et al., 2012). These intricate regulatory feedback loops among the Mitf variants probably evolved to ensure robust expression of Mitf, which is required for normal differentiation of an essential tissue for PR development and function (Bharti et al., 2012, Raviv et al., 2014).

Based on analyses of mouse mutants, the onset of Mitf expression is regulated by TFs expressed in the OV. Six3 seems to inhibit Mitf, possibly indirectly, through inhibition of Wnt8b (Liu et al., 2010), whereas Otx2 was found to directly regulate Mitf as well as to transactivate the expression of pigment genes in cooperation with Mitf (Martinez-Morales et al., 2003, Martinez-Morales et al., 2004). Similarly, Pax6 together with Pax2 are required for the onset of Mitf expression (Baumer et al., 2003). Pax6 also seems to regulate TFEC, which is upregulated upon Mitf loss in embryos with an intact Pax6 gene but not in double mutants of both Mitf and Pax6 (Bharti et al., 2012). Lhx2 is required for the expression of both Mitf and Chx10/Vsx2, the initiating factors for RPE and retina specification, respectively (Gordon et al., 2013, Yun et al., 2009). It is not clear whether Lhx2 directly regulates Mitf expression, as the consequences of Lhx2 loss include upregulation of hypothalamic and thalamic eminence genes, which may interfere with the acquisition of eye fates (Roy et al., 2013).

Restriction of Mitf expression to the prospective pigmented progenitors occurs in mice during the transition from $\mathrm{OV}$ to $\mathrm{OC}$ and is dependent on exogenous cues emanating from the surface ectoderm (SE) and the ocular mesenchyme (reviewed in Fuhrmann, 2010). Early studies using explants in chick embryos suggested that fibroblast growth factors (FGFs) emanating from the SE inhibit Mitf expression in the distal $\mathrm{OC}$ and thus enable upregulation of the NR TF, Vsx2 (Nguyen and Arnheiter, 2000). Vsx2 is important for NR progenitor proliferation and for inhibition of Mitf. In fish, Vsx2 also regulates the expression of proteins involved in $\mathrm{OC}$ morphogenesis (Gago-Rodrigues et al., 2015, Green et al., 2003, Nguyen and Arnheiter, 2000). As FGF-induced reprogramming of the RPE lineage does not occur in Vsx2-null mutant mice, it has been suggested that Vsx2 is an essential downstream node in the MAPK-FGF pathway responsible for NR fate determination (Horsford et al., 2005, Nguyen and Arnheiter, 2000).

Explant studies in chick embryos expose complex roles for TGF $\beta / B M P$ proteins in patterning and morphogenesis of neural plate and the OC. During early neurolation BMP activity in the anterior neural plate prevents the acquisition of eye-field identify from the prospective telencephalic cells, whereas, at the early neural tube stage BMP from the SE promote neural retina identity in adjacent OV (Pandit et al., 2015; Huang et al., 2015). Finally, TGF $\beta$ /BMP proteins, together with Wnt ligands emanating from the extraocular mesenchyme and SE around the lens are implicated in triggering RPE fate (Carpenter et al., 2015; Fuhrmann, 2010; Fuhrmann et al., 2000; Muller et al., 2007; Steinfeld et al., 2013; see below). A recent study using live imaging in zebrafish embryos indicated roles for BMPs in regulating the cellular move- 
ments required for $\mathrm{OC}$ morphogenesis, in addition to triggering RPE-differentiation genes. In this model, BMP controls the flow of cells from outside toward the inside of the developing $\mathrm{OC}$, and BMP-mediated inhibition of the flow results in ectopic NR in the RPE domain (Heermann et al., 2015). Whether cell migration contributes to $\mathrm{OC}$ morphogenesis and patterning in mammals, where proliferation plays a major role in expansion of the retinal progenitors, has yet to be determined.

Wnt signaling is another important pathway for RPE differentiation. Conditional inactivation of $\beta$-catenin, the mediator of the canonical Wnt pathway in the OV, using Lhx2-Cre (Hagglund et al., 2013), or in the presumptive RPE using Tryp1-Cre (Westenskow et al., 2009), prevents RPE differentiation and results in the formation of NR instead. Using chromatin immunoprecipitation and reporter assays, this phenotype is suspected to be a result of $\beta$-catenin's direct regulation of both Otx2 and Mitf (Fujimura et al., 2009, Westenskow et al., 2009). The regulation of Mitf by $\beta$ catenin has also been reported in melanocytes, where $\beta$-catenin functionally interacts with Mitf and is redirected by Mitf to activation of Mitf-specific target promoters (Lang et al., 2005, Schepsky et al., 2006); as such, this may represent a conserved pathway in pigmented cell differentiation.

In a recent study that explored the role of secreted Wnt ligands during mouse eye development, it was established that the autocrine secretion of Wnts by RPE cells is not sufficient for normal RPE differentiation. In contrast, Wnt ligands originating from the SE elicited specification of RPE progenitors near the OC rim. This suggestion was based on the observation that inhibition of Wnt ligands secretion from the SE reduces RPE cell number and results in a saucer-shaped OC (Carpenter etal., 2015). This abnormal OC morphology is consistent with the suggestion that RPE stiffness is an important driver for cup morphogenesis (Eiraku et al., 2011).

The Wnt ligands seem to affect both BMP and retinoic acid (RA) signaling pathways. Tissue ablation and transplantations in chick embryos suggest that Wnt ligands emanating from the dorsal SE direct dorsal OV cells to develop into RPE through a stabilizing effect of BMP signaling. BMPs and Wnts cooperate via a GSK3 $\beta$-dependent pathway at the level of pSmad to ensure RPE specification in dorsal OV cells (Steinfeld et al., 2013). Accordingly, upon loss of Lrp6, a Wnt receptor mediating canonical Wnt signaling, expression of both BMP and RA is reduced in the dorsal OC of mice (Zhou et al., 2008). Interestingly, RA seems to contribute to proliferation of the RPE as well as to affect the morphogenetic movements of the mesenchyme that surrounds the $\mathrm{OC}$ (Carpenter et al., 2015, Molotkov et al., 2006). Thus, it seems that Wnt is required for the generation of sufficient quantities of RPE cells through $\beta$-catenin and by regulating BMP, as well as for the RA-mediated morphogenetic movements of ocular mesenchyme.

Autonomous formation of OV and OC structures can be achieved from a 3D culture of mouse and human embryonic stem cells and induced pluripotent stem cell (iPSC) aggregates (Eiraku etal., 2011, Kuwahara et al., 2015, Meyer et al., 2011, Nakano et al., 2012). The isolated OC structures suggest an autonomous program for $\mathrm{OC}$ morphogenesis in the neural progenitors. Nevertheless, as these OC cultures are supplemented with Wnt ligands and RA ligands (Eiraku et al., 2011, Kuwahara et al., 2015, Nakano et al., 2012), it remains likely that in vivo, the SE is an important source of ligands which are required for RPE differentiation and normal OC morphogenesis.
Sonic hedgehog $(\mathrm{SHH})$ molecules play critical roles in establishing the bilateral eye fields and in determining the proximal-distal axis of the eye primordium (Chiang et al., 1996, Li et al., 1997, Macdonald et al., 1995). SHH also influences the expression patterns of BMP4 and Otx2 and thus may play a role in RPE development (Zhang and Yang, 2001). Recently, two antagonists of $\mathrm{HH}$ signaling in the $\mathrm{OC}$ were identified: Lrp2, a cell-surface receptor, mediates endocytic clearance of $\mathrm{SHH}$ and antagonizes its morphogenetic action (Christ et al., 2015) and Cdon, a celladhesion molecule that interacts with the $\mathrm{SHH}$ receptor Patched 1 (Ptc1) (Cardozo et al., 2014) and seems to antagonize $\mathrm{HH}$ by trapping the $\mathrm{HH}$ protein in the neuroepithelial basal end-foot. Cdon and LRP2 play a role in generation of the retina and adjacent ciliary body and iris, although their roles in RPE differentiation are unknown. Indian hedgehog $(\mathrm{IHH})$, secreted from endothelial cells adjacent to the RPE, is required for RPE differentiation. In mice mutated in $\mathrm{IHH}$, RPE differentiation is abnormal; the nuclei are elongated and deformed, the basal and apical microvilli are abrogated and pigmentation is reduced (Dakubo et al., 2008). Also the sclera and the retina are affected in the $\mathrm{IHH}$ mutant eyes and therefore the specific roles of IHH on RPE differentiation remain to be determined.

The Hippo signaling pathway was recently recognized to mediate the initial specification of RPE cells in fish embryos (Miesfeld et al., 2015). The Hippo kinase signaling cascade regulates cell-fate decisions during development by controlling the localization and stability of the transcriptional coactivators Yes-associated protein 1 (Yap) and WW domain containing transcription regulator 1 (Taz) (Varelas, 2014). The main nuclear binding partners for Yap and Taz are the Tea domain (Tead) TFs. Yap/Taz-Tead activity is necessary and sufficient for OV progenitors to adopt RPE identity in zebrafish. Yap mutants lack a subset of RPE cells and exhibit coloboma; the phenotype is exacerbated when combined with Taz mutant alleles, such that when Yap and Taz are both absent, OV progenitor cells completely lose their ability to form RPE. Consistent with the fact that mutation within the Yap-binding domain of Tead1 causes Sveinsson chorioretinal atrophy (SCRA), autosomal dominant loss of RPE and choroid, and altered choroid fissure closure (Fossdal et al., 2004, Jonasson et al., 2007), loss of function of Yap and Taz affects choroid fissure closure as well (Miesfeld et al., 2015). Current efforts are being aimed at determining the role of this pathway in mammalian RPE and deciphering the mechanisms upstream and downstream of the Yap/Taz-Tead activity in RPE specification and differentiation.

\section{Growth and differentiation of the retinal pigmented epithelium}

Growth and differentiation of the specified RPE occurs gradually, similar to the pattern of proliferation and differentiation in the adjacent NR (Defoe and Levine, 2003). In mice, on embryonic day 15 , there are approximately 14,000 RPE cells and by postnatal day 15 , the total number of RPE cells reaches 54,000, a fourfold increase (Bodenstein and Sidman, 1987). At the molecular level, it was shown in rats that the cyclin-dependent kinase inhibitor p27 (Kip1) is gradually upregulated, starting from the central OC and progressing toward the peripheral $\mathrm{OC}$, similar to the differentiation wave observed in the adjacent retina (Defoe and Levine, 2003). Expression of Kip1 decreases gradually during postnatal stages 


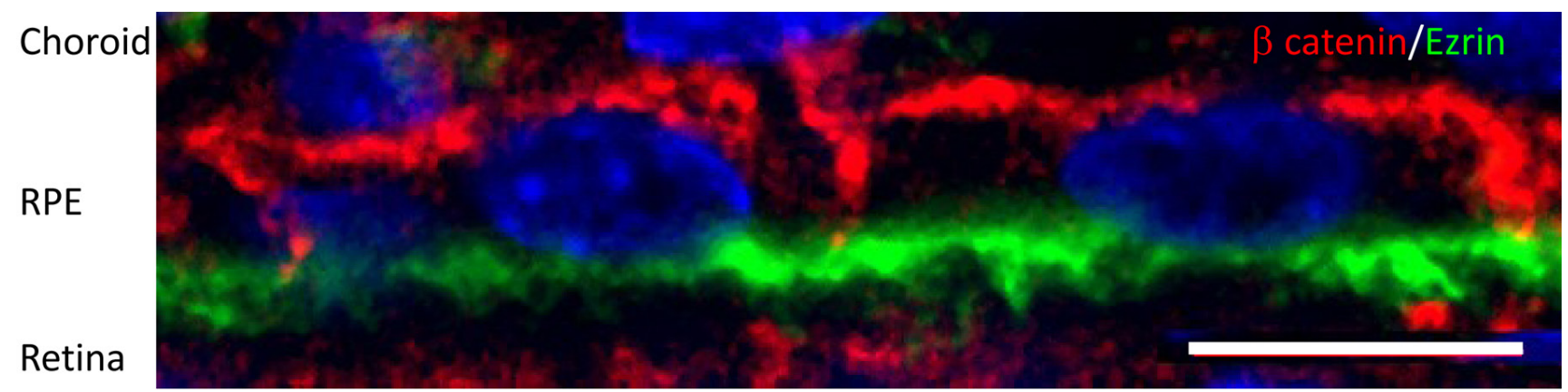

Fig. 1. Retinal pigmented epithelium (RPE) polarity at postnatal day 5 (P5) is evident with the accumulation of beta-catenin (red) in the basolateral membrane and phosphor-Ezrin (green) in the developing apical microvilli of the RPE. Nuclei are labeled with DAPI (b/ue). Scale bar, 10 um.

(Defoe and Levine, 2003). In addition to the increase in cell number due to proliferation, the RPE cells grow in size, so that the total area of the RPE increases 10-fold (Bodenstein and Sidman, 1987).

In contrast to the tight coupling of differentiation and cell-cycle exit observed in neural differentiation, differentiation is evident early on in RPE progenitors, with the accumulation of pigment granules (melanosomes). During embryogenesis as well, features of apical-basal polarity are evident with the apical localization in the developing microvilli of the scaffold protein phospho-ezrin, the basolateral distribution of beta-catenin and the basal deposition of components of Bruch's membrane, the basement membrane for both RPE and choriocapillary endothelium and an important component of the BRB (Bonilha et al., 2006; Hirabayashi et al., 2003; Fig. 1). RPE completes its differentiation during postnatal stages, in conjunction with choroid maturation and PR outer segment formation. These late events include the onset of expression of proteins involved in recycling and the continuous supply of 11-cis-retinal to PRs, growth of the apical microvilli, and establishment of the BRB, which is dependent on the formation of adherent tight junctions between the cells and on the polar distribution of ion channels and transporters that are required for selective transport across the barrier (reviewed in Rahner et al., 2004; Rizzolo et al., 2011; Lehmann et al., 2014).

\section{Gene regulatory networks in the late stages of retinal pigmented epithelium differentiation}

The gradual differentiation of RPE cells is mediated by the hierarchical expression of key TFs (Fig. 2). Pax6, which is important at early stages of RPE specification, is also required later on for the pigmentation of RPE cells. During this process, Pax6 regulates the RPE-specific D-isoform of Mitf (Bharti et al., 2008) and interacts in a feed-forward regulatory loop with Mitf proteins to activate the pigment-biogenesis genes (Cavodeassiand Bovolenta, 2014, Raviv et al., 2014). Around midgestation (Fig. 2B), expression of the TF Sox 9 is upregulated and probably promotes, based on bovine cellbased assays, the expression of genes related to the visual cycle through a synergistic cooperation with Lhx2 and Otx2 (Masuda et al., 2014). Sox9 has been further shown to regulate the expression of Best1, a Ca-dependent $\mathrm{Cl}$ channel, through interaction with Mitf and Otx2 (Esumi et al., 2007, Esumi et al., 2009, Masuda and Esumi, 2010). Moreover, conditional mutation of Otx2 in the adult mouse RPE provided further support for its requirement for RPE physiology (Housset et al., 2013). Together, these findings support key roles for Sox9 and Otx2 in regulating genes that are important for the diversity of RPE functions in adults.

In addition to TFs, microRNAs (miRNAs) have been shown to have an important role in RPE maturation and function (Sundermeier and Palczewski, 2016). Ohana et al., (2015) reported that RPE cells, in which miRNAs were diminished due to conditiona mutation in Dicer1 or DgcR8, preserve the expression of RPE TFs Sox9 and Otx2, but the cells are smaller than normal, show reduced pigmentation and fail to express enzymes required for the recycling of retinal (Ohana et al., 2015). miR204 which is essential for normal lens and retinal development in fish is highly enriched, together with miR211, its closely related paralog in mammals, in the developing and differentiated RPE (Conte et al., 2010, Ohana et al., 2015). A dominant gain-of-function mutation in miR204 resulted in a severe ocular phenotype, supporting an important role for this miRNA in multiple eye lineages in humans (Conte et al., 2015). Further support for miR204's role in the RPE was obtained through functional studies in primary human fetal RPE cultures, which revealed TGFBR2 and Snail2 to be direct targets of miR204/211, indicating the importance of this miRNA family in maintaining cell-adhesion properties and in RPE physiology (Wang et al., 2010). Interestingly, in the mammalian genome, miR211 and miR204 are encoded by two genes which are located within introns of the transient receptor potential genes Trpm1 and Trpm3, and these miRNAs seem to be co-regulated with their host genes. Trpm1/miR211 were found to be direct transcriptional targets of Mitf in primary cultures of human fetal RPE and melanocytes (Adijanto et al., 2012, Levy et al., 2010), while Pax6 was found to regulate Trpm3/miR204 in the lens, retina, ciliary body progenitors and iris (Shaham et al., 2013). Thus miR211 and miR204 are important mediators of key TFs required for differentiation of diverse eye lineages.

The levels of additional miRNAs are elevated during differentiation of RPE from pluripotent stem cells (Greene et al., 2014, Hu et al., 2012, Wang et al., 2014, Yuan et al., 2015), but very little is known about their expression profiles or functions in vivo at early developmental stages. Recent in-vitro functional studies using RPE generated from iPSCs have implicated roles for miR184 in promoting RPE differentiation by inhibiting the AKT2/mTOR signaling pathway (Jiang et al., 2016). Additional in-vitro studies on miRNAs in mature RPE have suggested that the visual cycle genes may be regulated by miR137 (Masuda et al., 2014), while catalase, an important component of the cell's antioxidant defense mechanism, seems to be regulated by miR30b (Haque et al., 2012). These studies support important roles for miRNAs in the RPE. However, 
considering possible redundancy between miRNAs and other compensatory mechanisms, further in-vivo functional studies are critical to substantiate the miRNAs' contributions to RPE development and function.

\section{RPE functions in the development of photoreceptors and choroidal vasculature}

The importance of the RPE for retinal development was documented early on by ablation of the embryonic RPE using targeted expression of toxins or misexpression of Fgf9, which resulted in the development of NR instead of RPE (Raymond and Jackson, 1995, Zhao and Overbeek, 2001). More recently, conditional mutations of Dicer1, DGCR8 or DNMT1 in the RPE were shown to result in failure to differentiate the PR outer segment (Nasonkin et al., 2013, Ohana et al., 2015). These findings demonstrate the importance of a functional RPE for PR outer segment formation and implicate the requirement of factors from the RPE for PR maturation.

Further support for the importance of RPE-secreted factors for PR differentiation comes from the observation that PRs grown in culture require supplementation of conditioned medium from RPE culture (Sheedlo et al., 2007). Moreover, it has been shown that different concentrations of RPE-conditioned medium drive retinal stem cells to different cell fates (Dutt et al., 2010). One candidate molecule for the mediation of RPE-PR communication is pigmented epithelium-derived factor (PEDF). In vitro, PEDF was able to rescue PR development (Jablonski et al., 2000). Nevertheless, a determination of the role of PEDF in PR differentiation awaits analysis of the retinal phenotype of PEDF mutant mice (Doll et al., 2003). Another suggested candidate is $\mathrm{SHH}$, as it is able to support PR development in vitro (Levine et al., 1997). However, while $\mathrm{HH}$ signalling is required for normal differentiation of the RPE (Dakubo et al., 2008), the HH ligand expressed in this tissue is not known. Thus, although there is ample evidence for the importance of RPEsecreted factors in PR differentiation, identification of these factors constitutes an important challenge for future studies. Understanding the interaction between the RPE and PRs is critical for the use of RPE-based therapies for retinal degenerative pathologies, as it can lead to better-directed therapies. In addition, it may provide a more indicative tool for the evaluation of RPE function and maturity.

The impact of RPE on PR differentiation can be also indirect, through its role in regulating development of the choroidal vascu-

A Patterning/specification Pigmentation

Pax6

Otx2

Lhx2

Mitf

miR204/211

Sox9

B

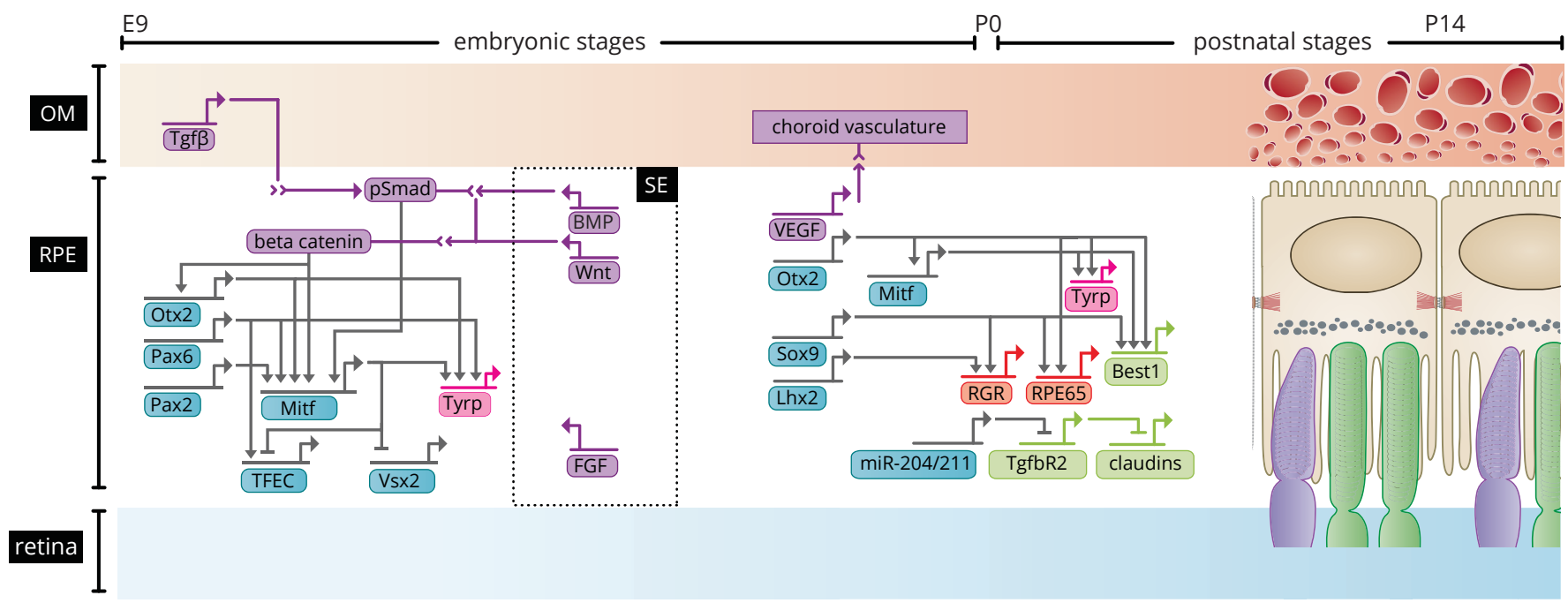

Fig. 2. Gene regulatory networks in retinal pigmented epithelium (RPE) differentiation. (A) The level of expression of transcription factors and miR204/211 family during RPE differentiation, demonstrated by color intensity and respectively to mouse embryonic stages mentioned in B. (B) The early and late regulatory networks of the RPE expressed genes and the signaling pathways mediating interaction with adjacent surface ectoderm (SE), retina and ocular mesenchyme (OM) from which the choroid vasculature evolves. The transcription factors or miRNAs are in blue, while their targets are labeled according to color code mentioned at top based on the biological function. The mature RPE cells and their adjacent tissues are illustrated on the lower right panel. 
lature and mediating the selective transport, and thus the microenvironment, required for PR differentiation, survival and physiology. This vascular system starts to form early on during vertebrate eye development (Gage et al., 2005), yet the molecular mechanisms regulating its formation are only starting to be uncovered. The RPE seems to be essential for choroid blood vessels' formation, as well as maintenance as the chemical destruction or transdifferentiation of the RPE resulted in abnormal choroid development (Korte et al., 1984, Zhao and Overbeek, 2001). Accordingly, co-culture of RPE cells with bovine choroidal endothelial cells stimulated the formation of the typical mesh network of the choriocapillaris. Interestingly, this stimulatory angiogenesis was attenuated by inhibition of VEGF and FGF, but was not affected by TGF $\beta$ neutralization (Sakamoto et al., 1995).

Further examination of the molecular signals from the RPE which may regulate choroid development and maintenance focused on proteins that are secreted to its basal side (Blaauwgeers etal., 1999). VEGF polar secretion (Blaauwgeers et al., 1999) was established to be essential for choroid development, since mice with conditional mutagenesis of VEGF in the RPE failed to develop choriocapillaris and demonstrated a microphthalmic phenotype. This was not observed following Hif1 a mutagenesis and was thus considered independent of the Hif1a pathway (Marneros et al., 2005). In addition to VEGF expression by the RPE during choroid development, its expression is maintained in the adult, suggesting a continuous role for VEGF in maintenance of the choroidal vasculature (Saint-Geniez et al., 2006, Zhao and Overbeek, 2001). Different isoforms of VEGF are generated by alternative exon splicing and contain 0 to 2 heparan sulfate sites, which affect their solubility (Tischer et al., 1991). The main isoforms expressed by the adult RPE are the soluble isoforms VEFG164 and VEFG120 (Saint-Geniez et al., 2006). Examination of mice expressing only the insoluble isoform, VEFG188, emphasized the need for soluble isoforms since their absence resulted in VEGF's inability to diffuse through Bruch's membrane and led to decreased phosphorylation of the VEGF receptor VEFGR2 in the choroid (Saint-Geniez et al., 2009).

FGF was shown to be a more potent angiogenic factor than VEGF (Cao et al., 2003). Nevertheless, the role of FGF2 in choroid vascularization is currently under debate; FGF2 administration induces choroidal angiogenesis (Soubrane et al., 1994), while Fgf2 null mice demonstrate normal development of choroid vessels (Ozaki et al., 1998). This contradiction may be settled by the ability of other FGF proteins, such as FGF5, to compensate for the loss of FGF2. This hypothesis was supported when transgenic mice expressing a dominant negative FGFR1 demonstrated delayed and decreased vascularization of the choroid (Rousseau et al., 2000). However, it is still unclear whether FGF affects choroidal angiogenesis directly or via other signaling pathways of the RPE. One suggestion for such a pathway is the coupling of FGFR2 upon activation with $\mathrm{Ca}^{2+}$ L-type channels (Rosenthal et al., 2001), which have been shown to promote VEGF secretion from RPE cells (Strauss et al., 2003).

\section{Generating RPE from pluripotent stem cells for the modeling of RPE development and diseases, and for cell-based therapy for retinal degeneration}

The 3D OC presents an excellent model to study early stages of retina and RPE development, while late stages of retinogenesis, as well as complete differentiation, are limited under long-term culture conditions. However, there have been great advances in the generation of differentiated RPE from human pluripotent stem-cells using 2D cultures, which are currently being tested in clinical settings as well as employed to model RPE diseases (extensively reviewed in Carr et al., 2013; Wahlin et al., 2014; Zhang et al., 2013). Initially, the differentiation protocols for RPE in 2D culture were generated by spontaneously differentiating colonies (Buchholz et al., 2009, Kawasaki et al., 2002, Klimanskaya et al., 2004). Later, enhanced differentiation efficiency was achieved by stepwise protocols that took into account knowledge of RPE-differentiation mechanisms in vivo, as well as factors that inhibit epithelial to mesenchyme transition (EMT) and support cell survival in culture (Buchholz et al., 2009; Buchholz et al., 2013; Idelson et al., 2009; Lamba et al., 2006; Maruotti et al., 2013; Osakada et al., 2009; Zahabi et al., 2012; Zhu et al., 2013; reviewed in Parvini et al., 2014). Important advances were made with the introduction of reporters for RPE differentiation, which are triggered by promoters of RPE genes such as RPE65, Mitf D, Otx2 and Bestrophin (Leach et al., 2015, Zhang et al., 2014). These reporters further enhanced the ability to monitor differentiation following manipulation of the cells with small molecules, ligands of signaling pathways or expression of TFs to enhance effective differentiation, and even direct conversion to RPE from fibroblasts (Maruotti et al., 2015, Zhang et al., 2014).

The successful generation of RPE from pluripotent cells allows researchers to model diseases ex vivo by employing patient-derived iPSCs. Cellular models for RPE dystrophies have been generated for Best disease (Singh et al., 2013), and mutations in frizzledrelated proteins (Li et al., 2014) and Mer tyrosine kinase receptor (MERTK; Lukovic et al., 2015). The findings obtained from these cellular models have contributed to our understanding of disease pathologies in humans and are expected to provide useful tools to test therapies (Lukovic et al., 2015).

The progress in generating RPE from stem cells has led to recent clinical trials in which these cells are used for therapy of AMD (Lu et al., 2016, Song et al., 2015). However, variability in differentiation efficiency among donors has to be considered, as well as the possibility that growth factors and chemicals that stimulate differentiation or expression of stem cell genes are not completely inactivated and that unexpected gene activities may appear, at least in some of the genetic backgrounds. These concerns have indeed had a major impact on the ongoing clinical trial with the detection of oncogene expression in RPE generated from iPSCs; a major challenge is to determine the level of differentiation of these cells in culture and following transplantation (Miyagishima et al., 2016). Another major challenge is to determine the capacity of the stem cell-derived RPE to functionally integrate the choroid and PRs for long-term tissue replacement. Future studies should therefore aim to provide a deeper understanding of the crosstalk between RPE and PRs and between RPE and choroid during development, differentiation and maintenance. Such findings will contribute to our understanding of the mechanism of organ formation, provide insights into the etiology of congenital retinal diseases and hopefully, lead to improved approaches for cell-replacement therapies.

To conclude, although great advances have been made in developing stem cell-based therapies for RPE diseases, there remains a need for a more comprehensive basic science understanding of the intrinsic program, as well as of the signaling to and from the RPE during eye development. Resolving TFs, miRNAs and epigenetic components that regulate RPE differentiation and 
the generation of adjacent lineages is critical for trials aimed at reducing heterogeneity between iPSCs, to improve differentiation and safety and to ensure proper integration and function within the host tissue to assure effective and safe cell-replacement therapies.

\section{Acknowledgment and funding}

We thank Amiel Dror for the illustrations. Research in the R.A.-P. Laboratory is supported by grants from Israel Science Foundation [228/14], Israel Science Foundation - National Science Foundation China joint research program (2469/16), United States-Israel Binational Science Foundation [2013016], Bright Focus Foundation and by the Claire and Amédée Maratier Institute for the Study of Blindness and Visual Disorders, Tel-Aviv University. Y C-T was supported by the Fisher Award for PhD students.

\section{References}

ADIJANTO, J., CASTORINO, J.J., WANG, Z.X., MAMINISHKIS, A., GRUNWALD, G.B. and PHILP, N.J. (2012). Microphthalmia-associated transcription factor (MITF) promotes differentiation of human retinal pigment epithelium (RPE) by regulating microRNAs-204/211 expression. J Biol Chem 287: 20491-20503.

ARENDT, D. (2003). Evolution of eyes and photoreceptor cell types. Int J Dev Biol 47: 563-571.

BAUMER, N., MARQUARDT, T., STOYKOVA, A., SPIELER, D., TREICHEL, D., ASHERY-PADAN, R. and GRUSS, P. (2003). Retinal pigmented epithelium determination requires the redundant activities of Pax2 and Pax6. Development 130: 2903-2915.

BEBY, F. and LAMONERIE, T. (2013). The homeobox gene Otx2 in development and disease. Exp Eye Res 111: 9-16.

BHARTI, K., GASPER, M., OU, J., BRUCATO, M., CLORE-GRONENBORN, K., PICKEL, J. and ARNHEITER, H. (2012). A regulatory loop involving PAX6, MITF, and WNT signaling controls retinal pigment epithelium development. PLoS Genet 8: e1002757.

BHARTI, K., LIU, W., CSERMELY, T., BERTUZZI, S. and ARNHEITER, H. (2008). Alternative promoter use in eye development: the complex role and regulation of the transcription factor MITF. Development 135: 1169-1178.

BHUTTO, I. and LUTTY, G. (2012). Understanding age-related macular degeneration (AMD): relationships between the photoreceptor/retinal pigment epithelium/Bruch's membrane/choriocapillaris complex. Mol Aspects Med 33: 295-317.

BLAAUWGEERS, H.G., HOLTKAMP, G.M., RUTTEN, H., WITMER, A.N., KOOLWIJK, P., PARTANEN, T.A., ALITALO, K., KROON, M.E., KIJLSTRA, A., VAN HINSBERGH, V.W. et al., (1999). Polarized vascular endothelial growth factor secretion by human retinal pigment epithelium and localization of vascular endothelial growth factor receptors on the inner choriocapillaris. Evidence for a trophic paracrine relation. Am J Pathol 155: 421-428.

BODENSTEIN, L. and SIDMAN, R.L. (1987). Growth and development of the mouse retinal pigment epithelium. I. Cell and tissue morphometrics and topography of mitotic activity. Dev Biol 121: 192-204.

BONILHA, V.L. (2014). Retinal pigment epithelium (RPE) cytoskeleton in vivo and in vitro. Exp Eye Res 126: 38-45.

BONILHA, V.L., RAYBORN, M.E., SAOTOME, I., MCCLATCHEY, A.I. and HOLLYFIELD, J.G. (2006). Microvilli defects in retinas of ezrin knockout mice. Exp Eye Res 82: 720-729.

BOVOLENTA, P., MALLAMACI, A., BRIATA, P., CORTE, G. and BONCINELLI, E. (1997). Implication of OTX2 in pigment epithelium determination and neural retina differentiation. J Neurosci 17: 4243-4252.

BUCHHOLZ, D.E., HIKITA, S.T., ROWLAND, T.J., FRIEDRICH, A.M., HINMAN, C.R., JOHNSON, L.V. and CLEGG, D.O. (2009). Derivation of functional retinal pigmented epithelium from induced pluripotent stem cells. Stem Cells 27:2427-2434.

BUCHHOLZ, D.E., PENNINGTON, B.O., CROZE, R.H., HINMAN, C.R., COFFEY, P.J. and CLEGG, D.O. (2013). Rapid and efficient directed differentiation of human pluripotent stem cells into retinal pigmented epithelium. Stem Cells Transl Med 2: 384-393.

CAO, R., BRAKENHIELM, E., PAWLIUK, R., WARIARO, D., POST, M.J., WAHLBERG, E., LEBOULCH, P. and CAO, Y. (2003). Angiogenic synergism, vascular stability and improvement of hind-limb ischemia by a combination of PDGF-BB and FGF-2. Nat Med 9: 604-613.

CARDOZO, M.J., SANCHEZ-ARRONES, L., SANDONIS, A., SANCHEZ-CAMACHO, C., GESTRI, G., WILSON, S.W., GUERRERO, I. and BOVOLENTA, P. (2014). Cdon acts as a Hedgehog decoy receptor during proximal-distal patterning of the optic vesicle. Nat Commun 5: 4272.

CARPENTER, A.C., SMITH, A.N., WAGNER, H., COHEN-TAYAR, Y., RAO, S., WALLACE, V., ASHERY-PADAN, R. and LANG, R.A. (2015). Wnt ligands from the embryonic surface ectoderm regulate 'bimetallic strip' optic cup morphogenesis in mouse. Development 142: 972-982.

CARR, A.J., SMART, M.J., RAMSDEN, C.M., POWNER, M.B., DA CRUZ, L. and COFFEY, P.J. (2013). Development of human embryonic stem cell therapies for age-related macular degeneration. Trends Neurosci 36: 385-395.

CAVODEASSI, F. and BOVOLENTA, P. (2014). New functions for old genes: Pax6 and Mitf in eye pigment biogenesis. Pigment Cell Melanoma Res 27: 1005-1007.

CHARLTON-PERKINS, M. and COOK, T.A. (2010). Building a fly eye: terminal differentiation events of the retina, corneal lens, and pigmented epithelia. Curr Top Dev Biol 93: 129-173.

CHIANG, C., LITINGTUNG, Y., LEE, E., YOUNG, K.E., CORDEN, J.L., WESTPHAL, H. and BEACHY, P.A. (1996). Cyclopia and defective axial patterning in mice lacking Sonic hedgehog gene function. Nature 383: 407-413.

CHRIST, A., CHRISTA, A., KLIPPERT, J., EULE, J.C., BACHMANN, S., WALLACE, V.A., HAMMES, A. and WILLNOW, T.E. (2015). LRP2 Acts as SHH Clearance Receptor to Protect the Retinal Margin from Mitogenic Stimuli. Dev Cell35: 36-48.

CONTE, I., CARRELLA, S., AVELLINO, R., KARALI, M., MARCO-FERRERES, R. BOVOLENTA, P. and BANFI, S. (2010). miR-204 is required for lens and retinal development via Meis2 targeting. Proc Natl Acad Sci USA 107: 15491-15496.

CONTE, I., HADFIELD, K.D., BARBATO, S., CARRELLA, S., PIZZO, M., BHAT, R.S., CARISSIMO, A., KARALI, M., PORTER, L.F., URQUHART, J. et al., (2015). MiR204 is responsible for inherited retinal dystrophy associated with ocular coloboma. Proc Natl Acad Sci USA 112: E3236-E3245.

DAKUBO, G.D., MAZEROLLE, C., FURIMSKY, M., YU, C., ST-JACQUES, B., MCMAHON, A.P. and WALLACE, V.A. (2008). Indian hedgehog signaling from endothelial cells is required for sclera and retinal pigment epithelium development in the mouse eye. Dev Biol 320: 242-255.

DAVIS-SILBERMAN, N. and ASHERY-PADAN, R. (2008). Iris development in vertebrates; genetic and molecular considerations. Brain Res 1192: 17-28.

DE MELO, J., ZIBETTI, C., CLARK, B.S., HWANG, W., MIRANDA-ANGULO, A.L., QIAN, J. and BLACKSHAW, S. (2016). Lhx2 Is an Essential Factor for Retinal Gliogenesis and Notch Signaling. J Neurosci 36: 2391-2405.

DEFOE, D.M. and LEVINE, E.M. (2003). Expression of the cyclin-dependent kinase inhibitor p27Kip1 by developing retinal pigment epithelium. Gene Expr Patterns 3: 615-619.

DOLL, J.A., STELLMACH, V.M., BOUCK, N.P., BERGH, A.R., LEE, C., ABRAMSON, L.P., CORNWELL, M.L., PINS, M.R., BORENSZTAJN, J. and CRAWFORD, S.E. (2003). Pigment epithelium-derived factor regulates the vasculature and mass of the prostate and pancreas. Nat Med 9: 774-780.

DUTT, K., DOUGLAS, P. and CAO, Y. (2010). RPE-secreted factors: influence differentiation in human retinal cell line in dose- and density-dependent manner. $J$ Ocul Biol Dis Infor 3: 144-160

EIRAKU, M., TAKATA, N., ISHIBASHI, H., KAWADA, M., SAKAKURA, E., OKUDA, S., SEKIGUCHI, K., ADACHI, T. and SASAI, Y. (2011). Self-organizing optic-cup morphogenesis in three-dimensional culture. Nature 472: 51-56.

EMERSON, M.M., SURZENKO, N., GOETZ, J.J., TRIMARCHI, J. and CEPKO, C.L. (2013). Otx2 and Onecut1 promote the fates of cone photoreceptors and horizontal cells and repress rod photoreceptors. Dev Cell 26: 59-72.

ESUMI, N., KACHI, S., CAMPOCHIARO, P.A. and ZACK, D.J. (2007). VMD2 promoter requires two proximal E-box sites for its activity in vivo and is regulated by the MITF-TFE family. J Biol Chem 282: 1838-1850.

ESUMI, N., KACHI, S., HACKLER, L., JR., MASUDA, T., YANG, Z., CAMPOCHIARO, P.A. and ZACK, D.J. (2009). BEST1 expression in the retinal pigment epithelium is modulated by OTX family members. Hum Mol Genet 18: 128-141.

FARHY, C., ELGART, M., SHAPIRA, Z., ORON-KARNI, V., YARON, O., MENUCHIN, Y., RECHAVI, G. and ASHERY-PADAN, R. (2013). Pax6 is required for normal cell-cycle exit and the differentiation kinetics of retinal progenitor cells. PLOS One 8: e76489. 
FOSSDAL, R., JONASSON, F., KRISTJANSDOTTIR, G.T., KONG, A., STEFANSSON, H., GOSH, S., GULCHER, J.R. and STEFANSSON, K. (2004). A novel TEAD1 mutation is the causative allele in Sveinsson's chorioretinal atrophy (helicoid peripapillary chorioretinal degeneration). Hum Mol Genet 13: 975-981.

FUHRMANN, S. (2010). Eye morphogenesis and patterning of the optic vesicle. Curr Top Dev Biol 93: 61-84.

FUHRMANN, S., LEVINE, E.M. and REH, T.A. (2000). Extraocular mesenchyme patterns the optic vesicle during early eye development in the embryonic chick. Development 127: 4599-4609.

FUHRMANN, S., ZOU, C. and LEVINE, E.M. (2014). Retinal pigment epithelium development, plasticity, and tissue homeostasis. Exp Eye Res 123: 141-150.

FUJIMURA, N., TAKETO, M.M., MORI, M., KORINEK, V. and KOZMIK, Z. (2009). Spatial and temporal regulation of Wnt/beta-catenin signaling is essential for development of the retinal pigment epithelium. Dev Biol 334: 31-45.

GAGE, P.J., RHOADES, W., PRUCKA, S.K. and HJALT, T. (2005). Fate maps of neural crest and mesoderm in the mammalian eye. Invest Ophthalmol Vis Sci 46: 4200-4208.

GAGO-RODRIGUES, I., FERNANDEZ-MINAN, A., LETELIER, J., NARANJO, S. TENA, J.J., GOMEZ-SKARMETA, J.L. and MARTINEZ-MORALES, J.R. (2015). Analysis of opo cis-regulatory landscape uncovers Vsx2 requirement in early eye morphogenesis. Nat Commun 6: 7054.

GEHRING, W.J. (2014). The evolution of vision. Wiley Interdiscip Rev DevBio/3: 1-40. GORDON, P.J., YUN, S., CLARK, A.M., MONUKI, E.S., MURTAUGH, L.C. and LEVINE, E.M. (2013). Lhx2 balances progenitor maintenance with neurogenic output and promotes competence state progression in the developing retina. $J$ Neurosci 33: 12197-12207.

GREEN, E.S., STUBBS, J.L. and LEVINE, E.M. (2003). Genetic rescue of cell number in a mouse model of microphthalmia: interactions between Chx10 and G1-phase cell cycle regulators. Development 130: 539-552.

GREENE, W.A., MUNIZ, A., PLAMPER, M.L., KAINI, R.R. and WANG, H.C. (2014). MicroRNA expression profiles of human iPS cells, retinal pigment epithelium derived from iPS, and fetal retinal pigment epithelium. $J$ Vis Expe51589.

GUETA, K., DAVID, A., CHOHEN, T., MENUCHIN-LASOWSKI, Y., NOBEL, H., NARKIS, G., LI, L., LOVE, P., DE MELO, J., BLACKSHAW, S., WESTPHAL, H., ASHERY-PADAN, R. (2016). The stage-dependent roles of Ldb1 and functional redundancy with Ldb2 in mammalian retinogenesis. Development 143:4182-4192.

HAGGLUND, A.C., BERGHARD, A. and CARLSSON, L. (2013). Canonical Wnt/ beta-catenin signalling is essential for optic cup formation. PLoS One 8: e81158.

HAQUE, R., CHUN, E., HOWELL, J.C., SENGUPTA, T., CHEN, D. and KIM, H. (2012). MicroRNA-30b-Mediated Regulation of Catalase Expression in Human ARPE-19 Cells. PLoS One 7: e42542.

HEERMANN, S., SCHUTZ, L., LEMKE, S., KRIEGLSTEIN, K. and WITTBRODT, J. (2015). Eye morphogenesis driven by epithelial flow into the optic cup facilitated by modulation of bone morphogenetic protein. Elife 4: e05216.

HIRABAYASHI, Y., FUJIMORI, O. and SHIMIZU, S. (2003). Bruch's membrane of the brachymorphic mouse. Med Electron Microsc 36: 139-146.

HORSFORD, D.J., NGUYEN, M.T., SELLAR, G.C., KOTHARY, R., ARNHEITER, H. and MCINNES, R.R. (2005). Chx10 repression of Mitf is required for the maintenance of mammalian neuroretinal identity. Development 132: 177-187.

HOUSSET, M., SAMUEL, A., ETTAICHE, M., BEMELMANS, A., BEBY, F., BILLON, N. and LAMONERIE, T. (2013). Loss of Otx2 in the adult retina disrupts retinal pigment epithelium function, causing photoreceptor degeneration. $J$ Neurosci 33: 9890-9904.

HU, G., HUANG, K., YU, J., GOPALAKRISHNA-PILLAI, S., KONG, J., XU, H., LIU, Z., ZHANG, K., XU, J., LUO, Y. et al., (2012). Identification of miRNA signatures during the differentiation of hESCs into retinal pigment epithelial cells. PLOS One 7: e37224

HUANG, J., LIU, Y., FILAS, B., GUNHAGA, L. and BEEBE, D.C. (2015). Negative and positive auto-regulation of BMP expression in early eye development. Dev Biol 407: 256-264.

IDELSON, M., ALPER, R., OBOLENSKY, A., BEN-SHUSHAN, E., HEMO, I., YACHIMOVICH-COHEN, N., KHANER, H., SMITH, Y., WISER, O., GROPP, M. et al., (2009). Directed differentiation of human embryonic stem cells into functional retinal pigment epithelium cells. Cell Stem Cell 5: 396-408.

JABLONSKI, M.M., TOMBRAN-TINK, J., MRAZEK, D.A. and IANNACCONE, A. (2000). Pigment epithelium-derived factor supports normal development of photoreceptor neurons and opsin expression after retinal pigment epithelium removal. J Neurosci 20: 7149-57.

JACKSON, G.R., OWSLEY, C. and CURCIO, C.A. (2002). Photoreceptor degeneration and dysfunction in aging and age-related maculopathy. Ageing Res Rev1:381-396.

JIANG, C., QIN, B., LIU, G., SUN, X., SHI, H., DING, S., LIU, Y., ZHU, M., CHEN, $X$. and ZHAO, C. (2016). MicroRNA-184 promotes differentiation of the retinal pigment epithelium by targeting the AKT2/mTOR signaling pathway. Oncotarget 7: $52340-52353$

JONASSON, F., HARDARSON, S., OLAFSSON, B.M. and KLINTWORTH, G.K. (2007) Sveinsson chorioretinal atrophy/helicoid peripapillary chorioretinal degeneration: first histopathology report. Ophthalmology 114: 1541-1546.

KAWASAKI, H., SUEMORI, H., MIZUSEKI, K., WATANABE, K., URANO, F., ICHINOSE, H., HARUTA, M., TAKAHASHI, M., YOSHIKAWA, K., NISHIKAWA, S. et al., (2002). Generation of dopaminergic neurons and pigmented epithelia from primate ES cells by stromal cell-derived inducing activity. Proc Natl Acad Sci USA 99: 1580-1585.

KEVANY, B.M. and PALCZEWSKI, K. (2010). Phagocytosis of retinal rod and cone photoreceptors. Physiology (Bethesda) 25: 8-15.

KLIMANSKAYA, I., HIPP, J., REZAI, K.A., WEST, M., ATALA, A. and LANZA, R. (2004). Derivation and comparative assessment of retinal pigment epithelium from human embryonic stem cells using transcriptomics. Cloning Stem Cells 6: 217-245.

KOIKE, C., NISHIDA, A., UENO, S., SAITO, H., SANUKI, R., SATO, S., FURUKAWA, A., AIZAWA, S., MATSUO, I., SUZUKI, N. et al., (2007). Functional roles of Otx2 transcription factor in postnatal mouse retinal development. Mol Cell Biol 27: 8318-8329.

KORTE, G.E., REPPUCCI, V. and HENKIND, P. (1984). RPE destruction causes choriocapillary atrophy. Invest Ophthalmol Vis Sci 25: 1135-1145.

KUWAHARA, A., OZONE, C., NAKANO, T., SAITO, K., EIRAKU, M. and SASAI, Y. (2015). Generation of a ciliary margin-like stem cell niche from self-organizing human retinal tissue. Nat Commun 6: 6286.

KWAN, K.M., OTSUNA, H., KIDOKORO, H., CARNEY, K.R., SAIJOH, Y. and CHIEN, C.B. (2012). A complex choreography of cell movements shapes the vertebrate eye. Development 139: 359-372.

LAMBA, D.A., KARL, M.O., WARE, C.B. and REH, T.A. (2006). Efficient generation of retinal progenitor cells from human embryonic stem cells. Proc Natl Acad Sci USA 103: 12769-12774.

LANG, D., LU, M.M., HUANG, L., ENGLEKA, K.A., ZHANG, M., CHU, E.Y., LIPNER, S., SKOULTCHI, A., MILLAR, S.E. and EPSTEIN, J.A. (2005). Pax3 functions at a nodal point in melanocyte stem cell differentiation. Nature 433: 884-887.

LEACH, L.L., BUCHHOLZ, D.E., NADAR, V.P., LOWENSTEIN, S.E. and CLEGG, D.O. (2015). Canonical/beta-catenin Wnt pathway activation improves retinal pigmented epithelium derivation from human embryonic stem cells. Invest Ophthalmol Vis Sci 56: 1002-1013.

LEHMANN, G.L., BENEDICTO, I., PHILP, N.J. and RODRIGUEZ-BOULAN, E. (2014). Plasma membrane protein polarity and trafficking in RPE cells: past, present and future. Exp Eye Res 126: 5-15.

LEVINE, E.M., ROELINK, H., TURNER, J. and REH, T.A. (1997). Sonic hedgehog promotes rod photoreceptor differentiation in mammalian retinal cells in vitro. $J$ Neurosci 17: 6277-6288.

LEVY, C., KHALED, M., ILIOPOULOS, D., JANAS, M.M., SCHUBERT, S., PINNER, S., CHEN, P.H., LI, S., FLETCHER, A.L., YOKOYAMA, S. et al., (2010). Intronic miR-211 Assumes the Tumor Suppressive Function of Its Host Gene in Melanoma. Mol Cell 40: 841-9.

LI, H., TIERNEY, C., WEN, L., WU, J.Y. and RAO, Y. (1997). A single morphogenetic field gives rise to two retina primordia under the influence of the prechordal plate. Development 124: 603-615.

LI, Y., WU, W.H., HSU, C.W., NGUYEN, H.V., TSAI, Y.T., CHAN, L., NAGASAKI, T., MAUMENEE, I.H., YANNUZZI, L.A., HOANG, Q.V. et al., (2014). Gene therapy in patient-specific stem cell lines and a preclinical model of retinitis pigmentosa with membrane frizzled-related protein defects. Mol Ther 22: 1688-1697.

LIU, W., LAGUTIN, O., SWINDELL, E., JAMRICH, M. and OLIVER, G. (2010). Neuroretina specification in mouse embryos requires Six3-mediated suppression of Wnt8b in the anterior neural plate. J Clin Invest 120: 3568-3577.

LU, Y., HAN, L., WANG, C., DOU, H., FENG, X., HU, Y., FENG, K., WANG, X. and MA, Z. (2016). A comparison of autologous transplantation of retinal pigment epithelium (RPE) monolayer sheet graft with RPE-Bruch's membrane complex 
graft in neovascular age-related macular degeneration. Acta Ophthalmol. doi: 10.1111/aos.13054

LUKOVIC, D., ARTERO CASTRO, A., DELGADO, A.B., BERNAL MDE, L., LUNA PELAEZ, N., DIEZ LLORET, A., PEREZ ESPEJO, R., KAMENAROVA, K., FERNANDEZ SANCHEZ, L., CUENCA, N. et al., (2015). Human iPSC derived disease model of MERTK-associated retinitis pigmentosa. Sci Rep 5: 12910.

MACDONALD, R., BARTH, K.A., XU, Q., HOLDER, N., MIKKOLA, I. and WILSON, S.W. (1995). Midline signalling is required for Pax gene regulation and patterning of the eyes. Development 121: 3267-3278.

MARNEROS, A.G., FAN, J., YOKOYAMA, Y., GERBER, H.P., FERRARA, N., CROUCH, R.K. and OLSEN, B.R. (2005). Vascular endothelial growth factor expression in the retinal pigment epithelium is essential for choriocapillaris development and visual function. Am J Pathol 167: 1451-1459.

MARTINEZ-MORALES, J.R., DOLEZ, V., RODRIGO, I., ZACCARINI, R., LECONTE, L., BOVOLENTA, P. and SAULE, S. (2003). OTX2 activates the molecular network underlying retina pigment epithelium differentiation. JBiol Chem278:21721-21731.

MARTINEZ-MORALES, J.R., RODRIGO, I. and BOVOLENTA, P. (2004). Eye development: a view from the retina pigmented epithelium. Bioessays 26: 766-777.

MARUOTTI, J., SRIPATHI, S.R., BHARTI, K., FULLER, J., WAHLIN, K.J., RANGANATHAN, V., SLUCH, V.M., BERLINICKE, C.A., DAVIS, J., KIM, C. et al., (2015). Small-molecule-directed, efficient generation of retinal pigment epithelium from human pluripotent stem cells. Proc Natl Acad Sci USA 112: 10950-10955.

MARUOTTI, J., WAHLIN, K., GORRELL, D., BHUTTO, I., LUTTY, G. and ZACK, D.J. (2013). A simple and scalable process for the differentiation of retinal pigment epithelium from human pluripotent stem cells. Stem Cells Trans/ Med 2: 341-354.

MASUDA, T. and ESUMI, N. (2010). SOX9, through interaction with microphthalmiaassociated transcription factor (MITF) and OTX2, regulates BEST1 expression in the retinal pigment epithelium. J Biol Chem 285: 26933-26944.

MASUDA, T., WAHLIN, K., WAN, J., HU, J., MARUOTTI, J., YANG, X., IACOVELLI, J., WOLKOW, N., KIST, R., DUNAIEF, J.L. et al., (2014). SOX9 Plays a Key Role in the Regulation of Visual Cycle Gene Expression in the Retinal Pigment Epithelium. J Biol Chem. 289: 12908-12921.

MEYER, J.S., HOWDEN, S.E., WALLACE, K.A., VERHOEVEN, A.D., WRIGHT, L.S., CAPOWSKI, E.E., PINILLA, I., MARTIN, J.M., TIAN, S., STEWART, R. etal., (2011). Optic vesicle-like structures derived from human pluripotent stem cells facilitate a customized approach to retinal disease treatment. Stem Cells 29: 1206-1218.

MIESFELD, J.B., GESTRI, G., CLARK, B.S., FLINN, M.A., POOLE, R.J., BADER, J.R., BESHARSE, J.C., WILSON, S.W. and LINK, B.A. (2015). Yap and Taz regulate retinal pigment epithelial cell fate. Development 142: 3021-3032.

MIYAGISHIMA, K.J., WAN, Q., CORNEO, B., SHARMA, R., LOTFI, M.R., BOLES, N.C., HUA, F., MAMINISHKIS, A., ZHANG, C., BLENKINSOP, T. et al., (2016). In Pursuit of Authenticity: Induced Pluripotent Stem Cell-Derived Retinal Pigment Epithelium for Clinical Applications. Stem Cells Trans/ Med. 5: 1562-1574.

MOLOTKOV, A., MOLOTKOVA, N. and DUESTER, G. (2006). Retinoic acid guides eye morphogenetic movements via paracrine signaling but is unnecessary for retinal dorsoventral patterning. Development 133: 1901-1910.

MULLER, F., ROHRER, H. and VOGEL-HOPKER, A. (2007). Bone morphogenetic proteins specify the retinal pigment epithelium in the chick embryo. Development 134: 3483-3493.

MURANISHI, Y., TERADA, K., INOUE, T., KATOH, K., TSUJII, T., SANUKI, R., KUROKAWA, D., AIZAWA, S., TAMAKI, Y. and FURUKAWA, T. (2011). An Essential Role for RAX Homeoprotein and NOTCH-HES Signaling in Otx2 Expression in Embryonic Retinal Photoreceptor Cell Fate Determination. J Neurosci 31: 16792-16807.

NAKANO, T., ANDO, S., TAKATA, N., KAWADA, M., MUGURUMA, K., SEKIGUCHI, K., SAITO, K., YONEMURA, S., EIRAKU, M. and SASAI, Y. (2012). Self-formation of optic cups and storable stratified neural retina from human ESCs. Cell Stem Cell 10: 771-785.

NASONKIN, I.O., MERBS, S.L., LAZO, K., OLIVER, V.F., BROOKS, M., PATEL, K., ENKE, R.A., NELLISSERY, J., JAMRICH, M., LE, Y.Z. et al., (2013). Conditional knockdown of DNA methyltransferase 1 reveals a key role of retinal pigment epithelium integrity in photoreceptor outer segment morphogenesis. Development 140: 1330-1341.

NGUYEN, M. and ARNHEITER, H. (2000). Signaling and transcriptional regulation in early mammalian eye development: a link between FGF and MITF. Development 127: 3581-3591.

OHANA, R., WEIMAN-KELMAN, B., RAVIV, S., TAMM, E., PASMANIK-CHOR, M.,
RINON, A., NETANELY, D., SHAMIR, R., SALOMON, A.S. and ASHERY-PADAN, R. (2015). MicroRNAs of the RPE are essential for RPE differentiation and photoreceptor maturation. Development. 142: 2487-2498.

ORON-KARNI, V., FARHY, C., ELGART, M., MARQUARDT, T., REMIZOVA, L., YARON, O., XIE, Q., CVEKL, A. and ASHERY-PADAN, R. (2008). Dual requirement for Pax6 in retinal progenitor cells. Development 135: 4037-4047.

OSAKADA, F., JIN, Z.B., HIRAMI, Y., IKEDA, H., DANJYO, T., WATANABE, K., SASAI, Y. and TAKAHASHI, M. (2009). In vitro differentiation of retinal cells from human pluripotent stem cells by small-molecule induction. J Cell Sci 122: 3169-3179.

OZAKI, H., OKAMOTO, N., ORTEGA, S., CHANG, M., OZAKI, K., SADDA, S., VINORES, M.A., DEREVJANIK, N., ZACK, D.J., BASILICO, C. et al., (1998). Basic fibroblast growth factor is neither necessary nor sufficient for the development of retinal neovascularization. Am J Pathol 153: 757-765.

PANDIT, T., JIDIGAM, V.K., PATTHEY, C. and GUNHAGA, L. (2015). Neural retina identity is specified by lens-derived BMP signals. Development 142: 1850-1859.

PARVINI, M., SATARIAN, L., PARIVAR, K., JAVAN, M., TONDAR, M., AHMAD, S. and BAHARVAND, H. (2014). Human pluripotent stem cell-derived retinal pigmented epithelium in retinal treatment: from bench to bedside. Mol Neurobio/50: 597-612.

PHILIPS, G.T., STAIR, C.N., YOUNG LEE, H., WROBLEWSKI, E., BERBEROGLU, M.A., BROWN, N.L. and MASTICK, G.S. (2005). Precocious retinal neurons: Pax6 controls timing of differentiation and determination of cell type. Dev Biol 279: 308-321.

PICKER, A., CAVODEASSI, F., MACHATE, A., BERNAUER, S., HANS, S., ABE, G. KAWAKAMI, K., WILSON, S.W. and BRAND, M. (2009). Dynamic coupling of pattern formation and morphogenesis in the developing vertebrate retina. PLoS Biol 7: e1000214.

PORTER, F.D., DRAGO, J., XU, Y., CHEEMA, S.S., WASSIF, C., HUANG, S.P., LEE, E., GRINBERG, A., MASSALAS, J.S., BODINE, D. et al., (1997). Lhx2, a LIM homeobox gene, is required for eye, forebrain, and definitive erythrocyte development. Development 124: 2935-2944.

RAHNER, C., FUKUHARA, M., PENG, S., KOJIMA, S. and RIZZOLO, L.J. (2004) The apical and basal environments of the retinal pigment epithelium regulate the maturation of tight junctions during development. J Cell Sci 117: 3307-3318.

RAVIV, S., BHARTI, K., RENCUS-LAZAR, S., COHEN-TAYAR, Y., SCHYR, R., EVANTAL, N., MESHORER, E., ZILBERBERG, A., IDELSON, M., REUBINOFF, B. et al., (2014). PAX6 regulates melanogenesis in the retinal pigmented epithelium through feed-forward regulatory interactions with MITF. PLoS Genet 10: 1004360.

RAYMOND, S.M. and JACKSON, I.J. (1995). The retinal pigmented epithelium is required for development and maintenance of the mouse neural retina. Curr Biol 5: 1286-1295.

RIZZOLO, L.J., PENG, S., LUO, Y. and XIAO, W. (2011). Integration of tight junctions and claudins with the barrier functions of the retinal pigment epithelium. Prog Retin Eye Res 30: 296-323.

ROSENTHAL, R., THIEME, H. and STRAUSS, O. (2001). Fibroblast growth factor receptor 2 (FGFR2) in brain neurons and retinal pigment epithelial cells act via stimulation of neuroendocrine L-type channels (Ca(v)1.3). FASEB J 15: 970-977.

ROUSSEAU, B., DUBAYLE, D., SENNLAUB, F., JEANNY, J.C., COSTET, P., BIKFALVI, A. and JAVERZAT, S. (2000). Neural and angiogenic defects in eyes of transgenic mice expressing a dominant-negative FGF receptor in the pigmented cells. Exp Eye Res 71: 395-404.

ROY, A., DE MELO, J., CHATURVEDI, D., THEIN, T., CABRERA-SOCORRO, A. HOUART, C., MEYER, G., BLACKSHAW, S. and TOLE, S. (2013). LHX2 is necessary for the maintenance of optic identity and for the progression of optic morphogenesis. J Neurosci 33: 6877-6884

SAINT-GENIEZ, M., KURIHARA, T. and D'AMORE, P.A. (2009). Role of cell and matrix-bound VEGF isoforms in lens development. Invest Ophthalmol Vis Sci 50: 311-321.

SAINT-GENIEZ, M., MALDONADO, A.E. and D'AMORE, P.A. (2006). VEGF expression and receptor activation in the choroid during development and in the adult. Invest Ophthalmol Vis Sci 47: 3135-3142.

SAKAMOTO, T., SAKAMOTO, H., MURPHY, T.L., SPEE, C., SORIANO, D., ISHIBASHI, T., HINTON, D.R. and RYAN, S.J. (1995). Vessel formation by choroidal endothelial cells in vitro is modulated by retinal pigment epithelial cells. Arch Ophthalmol 113: 512-520.

SAMUEL, A., RUBINSTEIN, A.M., AZAR, T.T., BEN-MOSHE LIVNE, Z., KIM, S.H. and INBAL, A. (2016). Six3 regulates optic nerve development via multiple 
mechanisms. Sci Rep 6: 20267.

SCHEPSKY, A., BRUSER, K., GUNNARSSON, G.J., GOODALL, J., HALLSSON, J.H., GODING, C.R., STEINGRIMSSON, E. and HECHT,A. (2006). The microphthalmiaassociated transcription factor Mitf interacts with beta-catenin to determine target gene expression. Mol Cell Biol 26: 8914-8927.

SHAHAM, O., GUETA, K., MOR, E., OREN-GILADI, P., GRINBERG, D., XIE, Q., CVEKL, A., SHOMRON, N., DAVIS, N., KEYDAR-PRIZANT, M. et al., (2013). Pax6 Regulates Gene Expression in the Vertebrate Lens through miR-204. PLoS Genet 9: e1003357.

SHAHAM, O., MENUCHIN, Y., FARHY, C. and ASHERY-PADAN, R. (2012). Pax6 a multi-level regulator of ocular development. Prog Retin Eye Res 31: 351-376.

SHEEDLO, H.J., BARTOSH, T.J., WANG, Z., SRINIVASAN, B., BRUN-ZINKERNAGEL, A.M. and ROQUE, R.S. (2007). RPE-derived factors modulate photoreceptor differentiation: a possible role in the retinal stem cell niche. In vitro Cell Dev Biol Anim 43: 361-370.

SINGH, R., SHEN, W., KUAI, D., MARTIN, J.M., GUO, X., SMITH, M.A., PEREZ, E.T., PHILLIPS, M.J., SIMONETT, J.M., WALLACE, K.A. et al., (2013). iPS cell modeling of Best disease: insights into the pathophysiology of an inherited macular degeneration. Hum Mol Genet 22: 593-607.

SINN, R. and WITTBRODT, J. (2013). An eye on eye development. Mech Dev 130: 347-358.

SONG, M.J. and BHARTI, K. (2015). Looking into the future: Using induced pluripotent stem cells to build two and three dimensional ocular tissue for cell therapy and disease modeling. Brain Res. 1638: 2-14

SONG, W.K., PARK, K.M., KIM, H.J., LEE, J.H., CHOI, J., CHONG, S.Y., SHIM, S.H., DEL PRIORE, L.V. and LANZA, R. (2015). Treatment of macular degeneration using embryonic stem cell-derived retinal pigment epithelium: preliminary results in Asian patients. Stem Cell Reports 4: 860-872.

SOUBRANE, G., COHEN, S.Y., DELAYRE, T., TASSIN, J., HARTMANN, M.P., COSCAS, G.J., COURTOIS, Y. and JEANNY, J.C. (1994). Basic fibroblast growth factor experimentally induced choroidal angiogenesis in the minipig. Curr Eye Res 13: 183-195

STEINFELD, J., STEINFELD, I., CORONATO, N., HAMPEL, M.L., LAYER, P.G., ARAKI, M. and VOGEL-HOPKER, A. (2013). RPE specification in the chick is mediated by surface ectoderm-derived BMP and Wnt signalling. Development 140: 4959-4969.

STRAUSS, G., KNAPE, I., MELZNER, I. and DEBATIN, K.M. (2003). Constitutive caspase activation and impaired death-inducing signaling complex formation in CD95-resistant, long-term activated, antigen-specific T cells. J Immunol 171: 1172-1182.

STRAUSS, O. (2005). The retinal pigment epithelium in visual function. Physiol Rev 85: $845-881$.

SUNDERMEIER, T.R. and PALCZEWSKI, K. (2016). The impact of microRNA gene regulation on the survival and function of mature cell types in the eye. FASEB J 30: 23-33.

TACHIBANA, M. (2000). MITF: a stream flowing for pigment cells. Pigment Cell Res 13: $230-240$.

TACHIBANA, M., PEREZ-JURADO, L.A., NAKAYAMA, A., HODGKINSON, C.A., LI, X., SCHNEIDER, M., MIKI, T., FEX, J., FRANCKE, U. and ARNHEITER, H. (1994). Cloning of MITF, the human homolog of the mouse microphthalmia gene and assignment to chromosome 3p14.1-p12.3. Hum Mol Genet 3: 553-557.

TISCHER, E., MITCHELL, R., HARTMAN, T., SILVA, M., GOSPODAROWICZ, D. FIDDES, J.C. and ABRAHAM, J.A. (1991). The human gene for vascular endothelial growth factor. Multiple protein forms are encoded through alternative exon splicing. J Biol Chem 266: 11947-11954.

VARELAS, X. (2014). The Hippo pathway effectors TAZ and YAP in development, homeostasis and disease. Development 141: 1614-1626.

WAHLIN, K.J., MARUOTTI, J. and ZACK, D.J. (2014). Modeling retinal dystrophies using patient-derived induced pluripotent stem cells. Adv ExpMed Biol801:157-164.

WANG, F.E., ZHANG, C., MAMINISHKIS, A., DONG, L., ZHI, C., LI, R., ZHAO, J. MAJERCIAK, V., GAUR, A.B., CHEN, S. et al., (2010). MicroRNA-204/211 alters epithelial physiology. FASEB J 24: 1552-1571.

WANG, H.C., GREENE, W.A., KAINI, R.R., SHEN-GUNTHER, J., CHEN, H.I., CAI $\mathrm{H}$. and WANG, Y. (2014). Profiling the microRNA Expression in Human iPS and iPS-derived Retinal Pigment Epithelium. Cancer Inform 13: 25-35.

WESTENSKOW, P., PICCOLO, S. and FUHRMANN, S. (2009). Beta-catenin controls differentiation of the retinal pigment epithelium in the mouse optic cup by regulating Mitf and Otx2 expression. Development 136: 2505-2510.

WRIGHT, A.F., CHAKAROVA, C.F., ABD EL-AZIZ, M.M. and BHATTACHARYA, S.S. (2010). Photoreceptor degeneration: genetic and mechanistic dissection of a complex trait. Nat Rev Genet 11: 273-284.

YUAN, Z., DING, S., YAN, M., ZHU, X., LIU, L., TAN, S., JIN, Y., SUN, Y., LI, Y. and HUANG, T. (2015). Variability of miRNA expression during the differentiation of human embryonic stem cells into retinal pigment epithelial cells. Gene569:239-249.

YUN, S., SAIJOH, Y., HIROKAWA, K.E., KOPINKE, D., MURTAUGH, L.C., MONUKI, E.S. and LEVINE, E.M. (2009). Lhx2 links the intrinsic and extrinsic factors that control optic cup formation. Development 136: 3895-3906.

ZAHABI, A., SHAHBAZI, E., AHMADIEH, H., HASSANI, S.N., TOTONCHI, M., TAEI, A., MASOUDI, N., EBRAHIMI, M., AGHDAMI, N., SEIFINEJAD, A. et al., (2012). A new efficient protocol for directed differentiation of retinal pigmented epithelia cells from normal and retinal disease induced pluripotent stem cells. Stem Cells Dev 21: 2262-2272.

ZHANG, K., LIU, G.H., YI, F., MONTSERRAT, N., HISHIDA, T., ESTEBAN, C.R. and IZPISUA BELMONTE, J.C. (2014). Direct conversion of human fibroblasts into retinal pigment epithelium-like cells by defined factors. Protein Cell 5: 48-58.

ZHANG, K., YI, F., LIU, G.H. and BELMONTE, J.C. (2013). New march towards the regeneration of sensation and cognition: hear more, see more and learn more. $\mathrm{J}$ Mol Cell Biol 5: 151-153.

ZHANG, X.M. and YANG, X.J. (2001). Temporal and spatial effects of Sonic hedgehog signaling in chick eye morphogenesis. Dev Biol 233: 271-290.

ZHAO, S. and OVERBEEK, P.A. (2001). Regulation of choroid development by the retinal pigment epithelium. Mol Vis 7: 277-282.

ZHOU, C.J., MOLOTKOV, A., SONG, L., LI, Y., PLEASURE, D.E., PLEASURE, S.J. and WANG, Y.Z. (2008). Ocular coloboma and dorsoventral neuroretinal patterning defects in Lrp6 mutant eyes. Dev Dyn 237: 3681-3689.

ZHU, Y., CARIDO, M., MEINHARDT, A., KURTH, T., KARL, M.O., ADER, M. and TANAKA, E.M. (2013). Three-dimensional neuroepithelial culture from human embryonic stem cells and its use for quantitative conversion to retinal pigment epithelium. PLoS One 8: e54552. 


\section{Further Related Reading, published previously in the Int. J. Dev. Biol.}

Retinal stem cells and regeneration

Ala Moshiri, Jennie Close and Thomas A. Reh

Int. J. Dev. Biol. (2004) 48: 1003-1014

http://www.intjdevbiol.com/web/paper/041870am

Formation of retinal pigment epithelium in vitro by transdifferentiation of neural retina cells M Opas, J R Davies, Y Zhou and E Dziak

Int. J. Dev. Biol. (2001) 45: 633-642

http://www.intjdevbiol.com/web/paper/11460999

Expression patterns of dystrophin products, especially of apodystrophin-1/Dp71, in the neural retina of Amphibian urodele Pleurodeles waltl

J P Arsanto, X Caubit, F Rivier, G Hugon, Y Thouveny and D Mornet

Int. J. Dev. Biol. (1999) 43: 75-83

http://www.intjdevbiol.com/web/paper/10213085

Lateral and radial growth uncoupled in reaggregated retinospheroids of embryonic avian retina

E Willbold, P Mansky and P G Layer

Int. J. Dev. Biol. (1996) 40: 1151-119

http://www.intjdevbiol.com/web/paper/9032020

Developmental regulation of acidic fibroblast growth factor (aFGF) expression in bovine retina

E Jacquemin, L Jonet, L Oliver, K Bugra, M Laurent, Y Courtois and J C Jeanny Int. J. Dev. Biol. (1993) 37: 417-423

http://www.intjdevbiol.com/web/paper/7507349

The ability of the epithelium of diencephalic origin to differentiate into cells of the ocular lens

G Juric-Lekic, F Bulic-Jakus, B Kablar and A Svajger

Int. J. Dev. Biol. (1991) 35: 231-237

http://www.intjdevbiol.com/web/paper/1814405
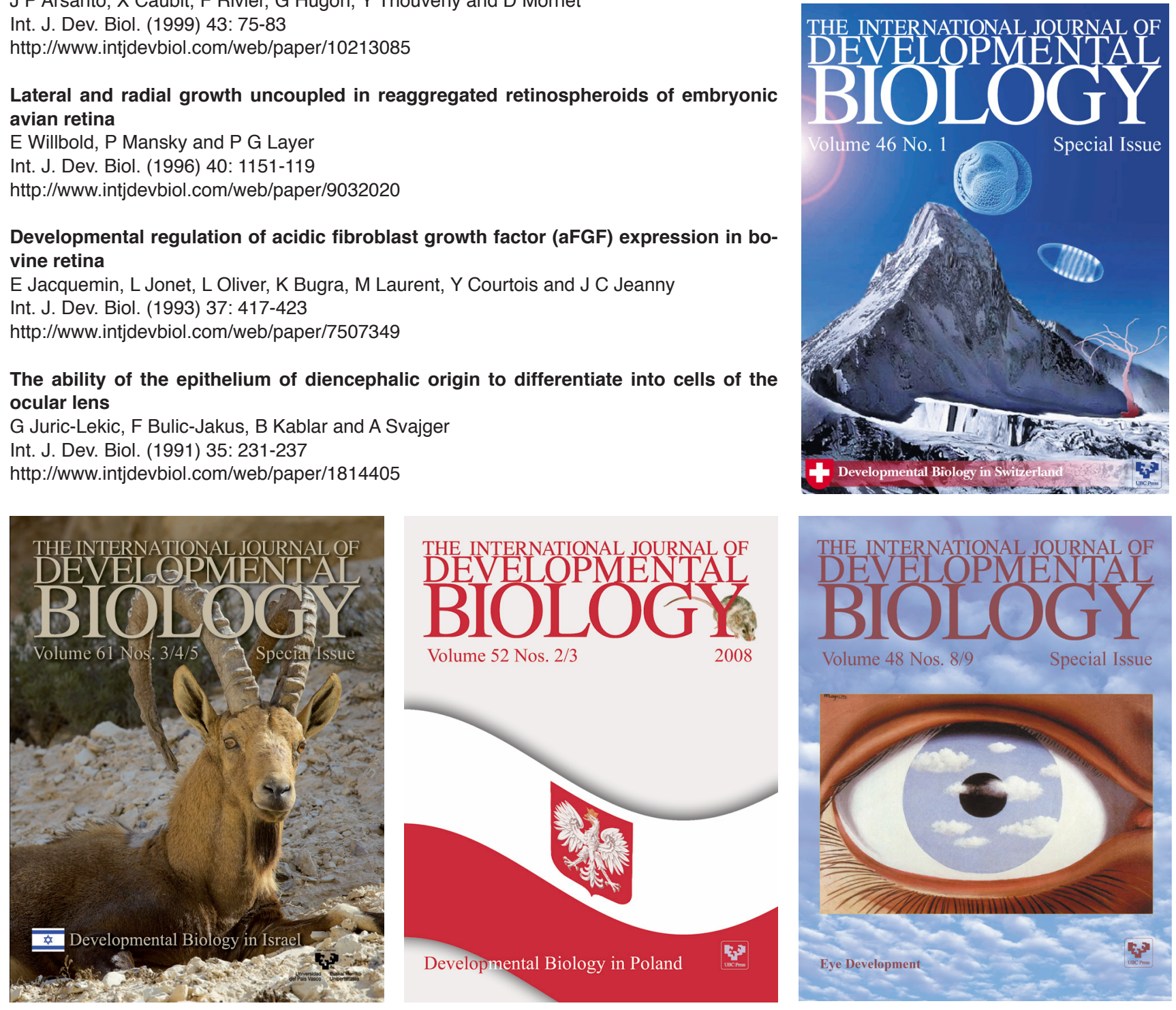